\title{
Article \\ Improvement of Intensive In-Seam Gas Drainage Technology at Kirova Mine in Kuznetsk Coal Basin
}

\author{
Sergey Slastunov ${ }^{1}$, Konstantin Kolikov ${ }^{1}$, Andrian Batugin ${ }^{1, *}$, Anatoly Sadov ${ }^{2}$ and Adam Khautiev ${ }^{2}$ \\ 1 Department of Mining Safety and Ecology, National University of Science and Technology (MISiS), \\ Leninsky Prospect 4, 119049 Moscow, Russia; slastunov.sv@misis.ru (S.S.); kolikov.ks@misis.ru (K.K.) \\ 2 JSC SUEK-Kuzbass, Vasilyeva Street 1, 652507 Leninsk-Kuznetsky, Russia; SadovAP@suek.ru (A.S.); \\ KhautievAM@suek.ru (A.K.) \\ * Correspondence: as-bat@mail.ru; Tel.:+7-9037571047
}

Citation: Slastunov, S.; Kolikov, K.; Batugin, A.; Sadov, A.; Khautiev, A. Improvement of Intensive In-Seam Gas Drainage Technology at Kirova Mine in Kuznetsk Coal Basin. Energies 2022, 15, 1047. https:// doi.org/10.3390/en15031047

Academic Editors:

Manoj Khandelwal, Abdul-Ghani Olabi,

Nikolaos Koukouzas and

Alireza Salmachi

Received: 17 September 2021

Accepted: 16 November 2021

Published: 30 January 2022

Publisher's Note: MDPI stays neutral with regard to jurisdictional claims in published maps and institutional affiliations.

Copyright: (c) 2022 by the authors. Licensee MDPI, Basel, Switzerland. This article is an open access article distributed under the terms and conditions of the Creative Commons Attribution (CC BY) license (https:// creativecommons.org/licenses/by/ $4.0 /)$.

\begin{abstract}
One of the ways to resolve the "green energy-economic development" dilemma, in which the coal industry is situated, is by the improvement of technologies and the integrated use of extracted resources, including methane gas as a clean energy source. Using the example of the Kirova mine, located in Kuznetsk coal basin-one of the ecologically unfavorable coal mining regions of Russiathis article discusses an integrated technology for the extraction of coalbed methane (ECBM), which makes it possible to reduce greenhouse gas (methane) emissions and improve the safety and intensity of coal mining. The Kirova mine, with its $3 \mathrm{Mt}$ production in 2019 , is one of the coal mining leaders in Russia. The available mining equipment has the potential to significantly increase the output; however, gas is a limiting factor to this. The customary approaches to coal seam degassing have already been petered out. The miners and mine science are facing a challenge to validate and test an alternative technology to ensure effective in-seam gas drainage prior to vigorous mining. This article gives an account of the improvement track record of the in-seam gas drainage technology used to pre-treat coal seams for intensive and safe extraction. This technology suggests, at the first stage, hydraulic loosening of the target coal seam through wells drilled from the surface (SSHL), then hydraulic fracturing (HF) of the coal seam through the boreholes drilled from underground development headings, followed by methane extraction from the high-permeability coal-gas reservoir created through standard in-seam gas drainage underground wells. Results are presented in this paper of field testing of the improved SSHL technique. Findings are presented on the effective parameters of the HF technology. Methodological recommendations are offered for selecting viable in-seam gas drainage technology.
\end{abstract}

Keywords: intensive coal mining; in-seam gas drainage; surface wells; hydraulic slotting; underground boreholes; hydraulic fracturing; in situ tests; improvement of technology

\section{Introduction}

For many decades, coal has been at the forefront of the global energy sector. In connection with the European Union's ambition to make Europe the first climate-neutral continent by 2050 [1] and the elimination of subsidies for the coal industry (Council Decision 2010/787/EU), a number of European countries are in the process of closing coal mines [2]. There are still protests against the construction of new mines [3,4] and different understandings of the role and position of the mining industry and mining science in society are being discussed [5,6]. At the same time, new coal mining enterprises are opening in China [7], India [8], Australia [9], Russia [10], and other countries [11,12]. Under these circumstances, one of the ways to preserve the ecological balance on the planet and solve the dilemma of "climate-trade" and "climate-production of hydrocarbons" [13] and "production-social and ecological risks" [14,15] is to improve technology and comprehensive use of minerals.

Coalbed methane (CBM) is a valuable energy source [16] and its use can reduce the impact of coal mining on the climate and the environment [17]. At the same time, methane is 
a limiting factor in high-productivity production, being one of the most dangerous factors in mining [18]. Safe and efficient coal mining is achieved through coal bed degassing (ECBM), which is carried out in underground mine workings [19], from the surface [20], or complexly [21].

Dozens of gas drainage methods and technologies are known internationally [22]. The most effectively used methods of gas drainage are those where methane is drained from the stress-relieved coal seam $[23,24]$. The effectiveness of these methods is over $80 \%$, which from a cause-and-effect viewpoint is due to the extraction of liberated gas. Whatever issues arise do not represent conceptual scientific problems and their solution depends on competent engineering support. In Russia, these methods are most representatively described in [25].

The situation is different with coal seams still exposed to strata pressure, where gas drainage efficiency is significantly lower [26]. In this situation, there are also other problems with mining $[27,28]$. Worldwide, a common approach to achieve high production from a face, while ensuring gas-related safety of the mining operations, is to apply the in-seam gas drainage technology (also called coalbed methane recovery). However, the efficiency of traditional technology is often very low [29]. To increase efficiency, various methods of impact on the coal seam have been developed: the method of hydraulic fracturing (HF) is widely used [30]. the ousting of methane by carbon dioxide [31,32] or water [33] is practiced, thermal impact [34-36] and auto-pneumatic impact (API) is applied, and various methods of changing reservoir properties or changing the stress state near drainage wells are used $[37,38]$. Hydraulic loosening (HL) is also used for permeability increases of the coal seams [39].

Equipment is being developed to equip drainage wells [40], work is underway to substantiate their parameters and the length of sealing zones [41,42], and modeling and laboratory experiments are being carried out $[43,44]$. The greatest effect is achieved when several methods are combined. For example, in the article by Zhu et al. [45], a method of alternating water and gas injection into the reservoir is proposed to improve drainage parameters. In the work of Li et al. [30], the authors propose to drill wells according to a tree-like scheme. In the work of Yan et al. [46], the authors propose to combine hydraulic fracturing and hydraulic slotting.

The problem of coalbed methane in Russia is very important both for safety and for the environment, since the gas content in layers reaches $16 \mathrm{~m}^{3} / \mathrm{t}$ and more [47]. The leader amongst coal mining regions of Russia is Kuzbass (Kuznetsk coal basin), where $220 \mathrm{Mt}$ of coal was mined in 2020. In Kuzbass, environmental problems are acute and the application of measures to protect the environment is required $[48,49]$. SUEK-Kuzbass JSC is one of the leaders in the coal industry in Kuzbass and Russia. In 2018, the company set a world record for monthly production from one longwall face- -1.7 million tons. The Kirova mine with its $3 \mathrm{Mt}$ production in 2019 is one of the key assets of the company. It is currently a single LW mine operating in the 2.2-m-thick Boldyrevsky Seam. The gas content in this seam averages $16 \mathrm{~m}^{3} / \mathrm{t}$. The company management aims to further increase production while maintaining the conditions for safe mining. The key limiting factor for further production intensification is the gas factor, which sets the task of ensuring effective and early in-seam gas drainage.

Yet, at depths of $400 \mathrm{~m}$ and below, the effectiveness of the in-seam gas drainage technology at SUEK-Kuzbass JSC mines is only 10-15\%. Therefore, the gas factor is the obvious bottleneck in the face output and impedes more intensive mining in high-gas coal seams. Hence, the challenge is to develop new effective coalbed gas drainage technologies.

At the initiative of the authors-and with the support of the company's managementin recent years, experimental and implementation work at Kirova mine to substantiate effective technological gas drainage systems has been carried out, and this work is ongoing. In this paper, we consider the experience of developing new (for Russia) integrated schemes for the stepwise degassing of the development areas, using the example of Kirova mine, 
which allow us to increase the rate of coal production and simultaneously to reduce the methane emissions to the environment.

\section{Methodology}

Improving the In-Seam Gas Drainage Technology Prior to Intense Underground Mining

The layout of the mine workings in the Boldyrevsky Seam is provided in Figure 1. The extraction blocks 2458, 2459, 2460, and 2462 were mined out in recent years; extraction blocks 2463 and 2464 have been in operation during 2019-2021. In blocks 2458, 2459, 2460, and 2462 , the standard technique, i.e., in-seam gas drainage from development headings, was applied as a baseline scheme since it has been well proven in the mines of Russia. The parameters of this standard technology are set out in the current guideline document: Gas Drainage Instructions [25].

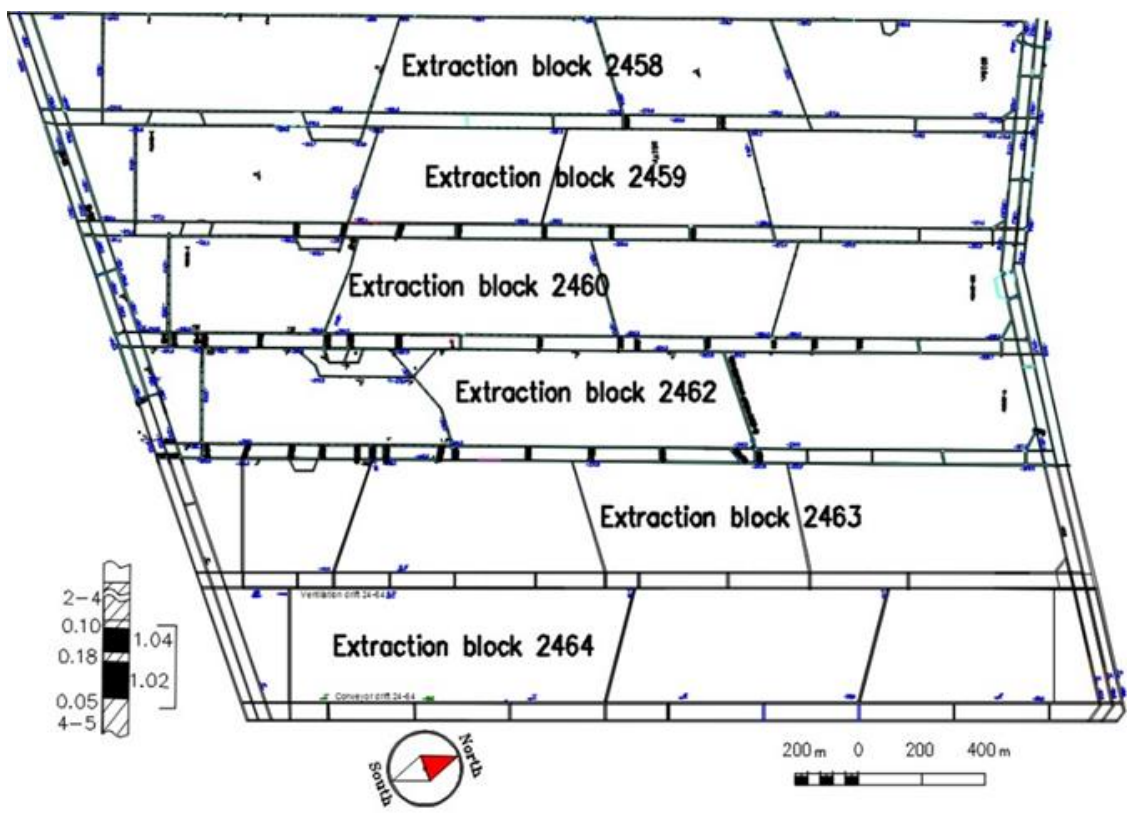

Figure 1. Mine workings layout in Boldyrevsky Seam.

In block 2458, the intense coal production, using the baseline gas drainage scheme, was supplemented by seam hydraulic fracturing technology. In this production block, hydraulic fracturing was performed from 12 underground wells (UgHF technology). The effectiveness of this auxiliary technological scheme was evaluated during coal-face operations. The following factors were taken into account: gas emission rate, resultant quantity of methane captured from the in-seam gas drainage wells, reduced amount of gas in production workings, reduced longwall downtime due to gas factor, and increased output from the production face.

An important aspect of the work carried out using this technology was the search for effective parameters of UgHF technology, primarily the effective length of UgHF wells. So, the plan for exploratory experimental studies on in-seam gas drainage in the extraction block 2460, Boldyrevsky Seam, includes the hydraulic fracturing operations with effective lengths of hydraulic fracturing wells varying at 5, 35, 70, and $110 \mathrm{~m}$ (Table 1). 
Table 1. Technical specifications of the ECBM for the block 2460 in Boldyrevsky seam (Hydrofracture location-vent. raise 2460).

\begin{tabular}{|c|c|c|c|}
\hline No & Parameter & Unit & Value \\
\hline 1. & $\begin{array}{l}\text { Effective length of hydrofracture } \\
\text { boreholes }\end{array}$ & M & $\begin{array}{c}110 \text { (for bh.9-13) } \\
70 \text { (for bh.14-18) } \\
35 \text { (for bh.19-23) } \\
5 \text { (for bh.24-28) }\end{array}$ \\
\hline 2. & Drill bit dia & $\mathrm{Mm}$ & 93-132 \\
\hline 3. & Casing pipe dia & $\mathrm{Mm}$ & 70 \\
\hline 4. & $\begin{array}{l}\text { Pump pressure at seam } \\
\text { hydrofracture }\end{array}$ & $\mathrm{MPa}$ & $12-30$ \\
\hline 5. & Fluid pumping rate & $1 / \mathrm{s}$ & unto 10 \\
\hline 6. & Seam hydro-conditioning radius & M & 25 \\
\hline 7. & $\begin{array}{l}\text { Quantity of fluid for } \\
\text { hydrofracture }\end{array}$ & $\mathrm{m}^{3}$ & $5-50$ \\
\hline 8. & $\begin{array}{l}\text { Min time of seam treatment } \\
\text { considering varied pumping rate }\end{array}$ & Min & 80 \\
\hline
\end{tabular}

As shown in Table 1, four zones were laid out in the extraction block 2460, where in-seam gas drainage was performed by underground hydraulic fracturing through wells with various effective lengths (i.e., lengths of the open/uncased part of the borehole). In the first group of wells No. 9-13 (zone 1 in Figure 2), the effective length of the hydraulic fracturing wells was $110 \mathrm{~m}$; in the second group of wells No. 14-18 (zone 2 in Figure 2), this parameter was $70 \mathrm{~m}$; in the third group of wells No. 19-23 (zone 3 in Figure 2), it was $35 \mathrm{~m}$; and in the fourth group of wells No. 24-28 (zone 4 in Figure 2), it was 5 m, respectively.

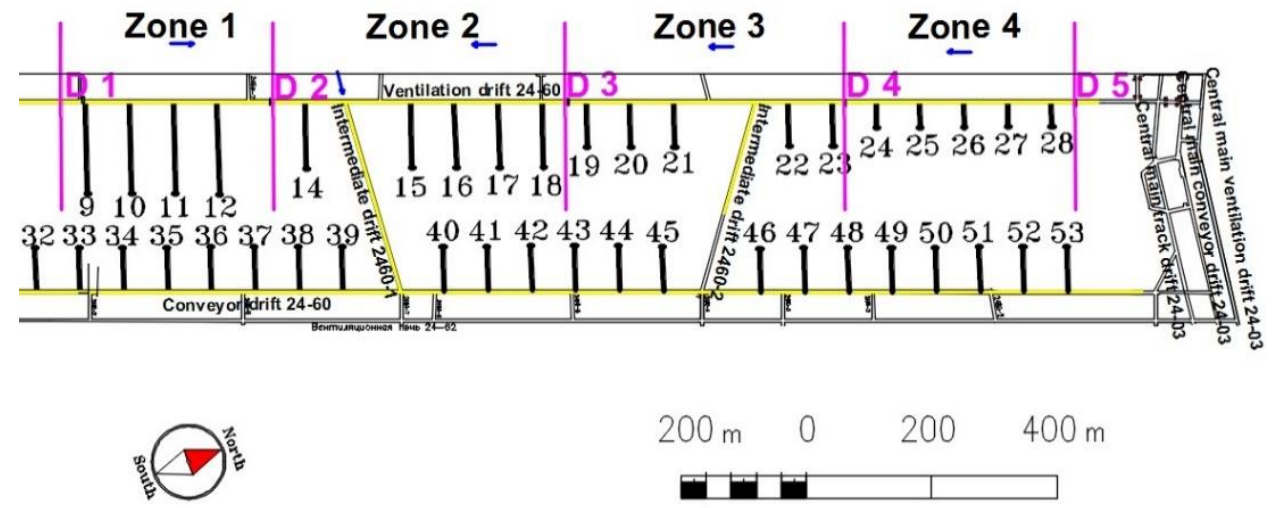

Figure 2. Location of UgHF wells of various lengths at extraction block 2460.

The length of the uncased part increases only when the hydraulic fracturing mode is achieved, i.e., when pressure is stabilized at a certain level while working fluid is being injected into the seam. The design quantity of working fluid for injection is $50 \mathrm{~m}^{3}$. The injection volume allowable, for various technological reasons (mainly liquid breakout into the mine working, water drip from under the roof bolts), can vary between 5 and $50 \mathrm{~m}^{3}$.

Concurrently, the technology of the auto-pneumatic impact on a coal seam was initially tested in extraction block 2455 [36]. During auto-pneumatic impact (API) on a coal seam, the sliding valve in a gas drainage well is shut off from time to time. When the valve is shut, the pressure in the well rises to the value that hypothetically levels off with that in the seam, hence increasing the coal seam permeability in the near-wellbore zone. 


\section{Results}

3.1. Results of Combining the In-Seam Gas Drainage Baseline Scheme with Seam Hydrofracture Technology

The very first results of the underground hydrofracture technique application in intensive coal extraction block 2458 demonstrated a 3- to 4-fold long-term (7-8 months prior to face breakthrough) increase in methane yield attributed to the in-seam gas drainage holes drilled in the fracture target areas. The average value of the relative gas content at the LW face was reduced by $30 \%$, process shutdowns due to "gas barrier" decreased by $42 \%$, and coal production was increased by $21 \%$ on average. Subsequently, the technology of underground hydraulic fracturing was successfully used in extraction blocks 2459, 2460, and 2462.

\subsection{The Results of the Underground Hydrofracture Parameter Optimization}

One of the key parameters of the underground hydrofracture technique is the effective length of the UgHF hole. The time-related changes in the amount of methane removed from wells in 2460 ventilation increase with different effective lengths, which is shown in Figure 3.

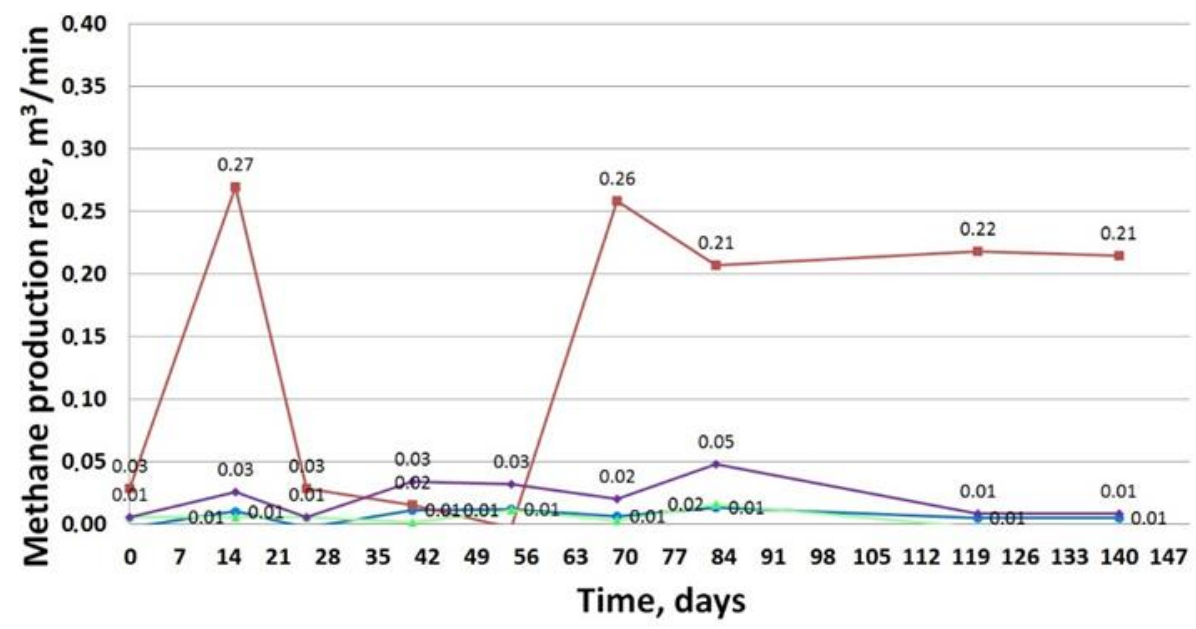

$\rightarrow$ Zone 1 -Zone $2 \rightarrow$ Zone $3 \rightarrow$ Zone 4

Figure 3. Time-related changing flow rate of methane from various effective length boreholes observed in ventilation raise 2460 .

The methane yield analysis shows that the integrated in-seam gas drainage process is most effective when the length of the wells is $70 \mathrm{~m}$ (red line in Figure 3).

At the present stage of research, our recommendation is a range of effective $\mathrm{UgHF}$ well lengths between 35 and $70 \mathrm{~m}$.

\subsection{Results of Combining the In-Seam Gas Drainage Baseline Scheme with the Technology of Pneumatic Impact on a Coal Seam}

Technological tests of the seam pneumatic impact in block 2455 provided the following data. In eight trial gas drainage wells, after the valve was shut off, the pressure rose to 2.0-2.5 MPa. Thereafter, the methane flow rate increased from 3-8 to 22-27 L/min, which significantly improved the effectiveness of the in-seam gas drainage.

The pneumatic impact technology probe is recommended as a method to stimulate gas release from slow-functioning typical underground wells of in-seam gas drainage.

\subsection{Results of Work on Degassing a Coal Seam by Wells from the Surface at the Experimental Site}

The results obtained on enhancing the effectiveness of in-seam gas drainage in hydraulically fractured zones in longwalls 2455, 2458, 2459, 2460, and 2462 served as the basis for launching a larger-scale program of gas drainage trial operations in extraction block 
2463 in 2019. It is here that it became possible to implement the already proven technology of early in-seam gas drainage through wells drilled from the surface (SSHL) $[39,47]$ in combination with hydraulic fracturing of the Boldyrevsky coal seam (UgHF).

The purpose of such integration is to achieve an even higher performance of the gas drainage in operations, both to ensure intense coal excavation and reduce methane emissions into the environment. The main idea of this experimental technology is to improve the reservoir properties (porosity and permeability) of a coal seam by creating a network of technogenic fractures by injecting water under high pressure.

The many-fold increase of the permeability and gas release potential of coal seams, achieved by their SSHL, is due to their changed stress-strain condition and the physical properties caused by the injection of working fluid in regimes exceeding the natural intake capacity of the seams. Such injection results in widening of natural fissures and/or the development of artificial fissures (all of them making up an integrated hydraulic system oriented towards the well), becoming a canal for the subsequent extraction of liquid and gas onto the surface. To prepare HL, a well is drilled to a target depth of 600-620 m, working with an (ultimate) core bit diameter being $159 \mathrm{~mm}$. The annular space is overlapped and thoroughly grouted to the entire depth, including overlying worked out formations. Wells are drilled from the surface, $0.5 \mathrm{~m}$ well depth span below the top of the seam is cased, and coal seam undergoes hydraulic slotting.

Selection of the viable in-seam gas drainage technology for individual geological and mining conditions is one of the most challenging issues. The key point here is the magnitude of the "gas barrier"; hence, adequate in-seam gas drainage effectiveness shall be defined. The nomogram on the required methane extraction as a result of in-seam gas drainage in the Boldyrevsky coal seam is shown in Figure 4 and allows us to make an adequate decision about the in-seam gas drainage option depending on the required output of the production face.

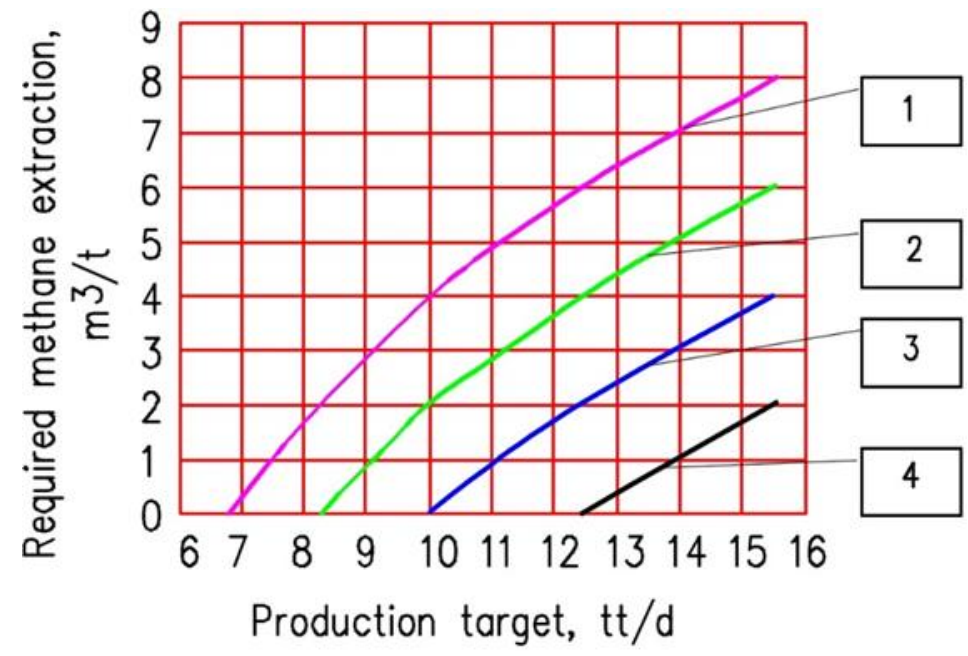

Figure 4. Methane extraction required to enhance production output depending on the baseline gas content of the coal seam: (1) $18 \mathrm{~m}^{3} / \mathrm{t}$; (2) $16 \mathrm{~m}^{3} / \mathrm{t}$; (3) $14 \mathrm{~m}^{3} / \mathrm{t}$; (4) $12 \mathrm{~m}^{3} / \mathrm{t}$ [50].

With an actual gas content of $16 \mathrm{~m}^{3} / \mathrm{t}$ in the extraction block 2463 of the Boldyrevsky seam and an estimated production target of $14,000.00 \mathrm{tpd}$, the required volume of methane removal in the process of in-seam gas drainage is $5 \mathrm{~m}^{3} / \mathrm{t}$. Based on the available data on the actual efficiency of in-seam gas drainage, the updated technology for early degassing of coal seams through surface wells (SSHL) was advised. The proven efficiency thereof is $0.3-0.5$ and it can provide methane extraction at the level of $5 \mathrm{~m}^{3} / \mathrm{t}$. The technology of in-seam gas drainage from underground development headings in SSHL zones with an extended grid of in-seam wells was recommended as a support measure. 
The first experimental area within the extraction block 2463 at Kirova mine covers six seam hydraulic loosening boreholes (SSHL) No. 1-6 drilled from the surface. Part of the program is to test a simplified SSHL procedure, whereby the target coal seam is not screened by a perforated pipe. After the well has been cased, the entire complex of equipment is moved down the hole and seam hydraulic loosening is performed by highpressure pumps with a total flow rate of up to $0.1 \mathrm{~m}^{3} / \mathrm{s}$. Some details of the technology are shown in the Supplementary Materials.

The pressure and flow rate are constantly monitored by gauges recording and visualizing data from a safe distance. The volume of water required for injection into one well is at least 500 to $1000 \mathrm{~m}^{3}$. After the completion of HL, the wells remain inactive for up to 8-12 months or until the start of mining operations. At the experimental stage, the selection of the working fluid from the well is brought to the surface with the removal of the methane; however, at a later stage, the water must be discharged into underground workings.

\section{Discussion and Further Development of the Integrated In-Seam Gas Drainage Technology}

4.1. Recommended Practice for Selecting the Most Viable Method of In-Seam Gas Drainage for High-Production Mining Panels

Based on the results obtained, recommendations were drafted on the selection of in-seam gas drainage methods for high-production mining panels, including two phases. At the first stage of drafting recommendations, the required performance of in-seam gas drainage is determined where the predicted gas yield, the time available for in-seam gas drainage, and the scheduled face output are taken into account (Figure 5).

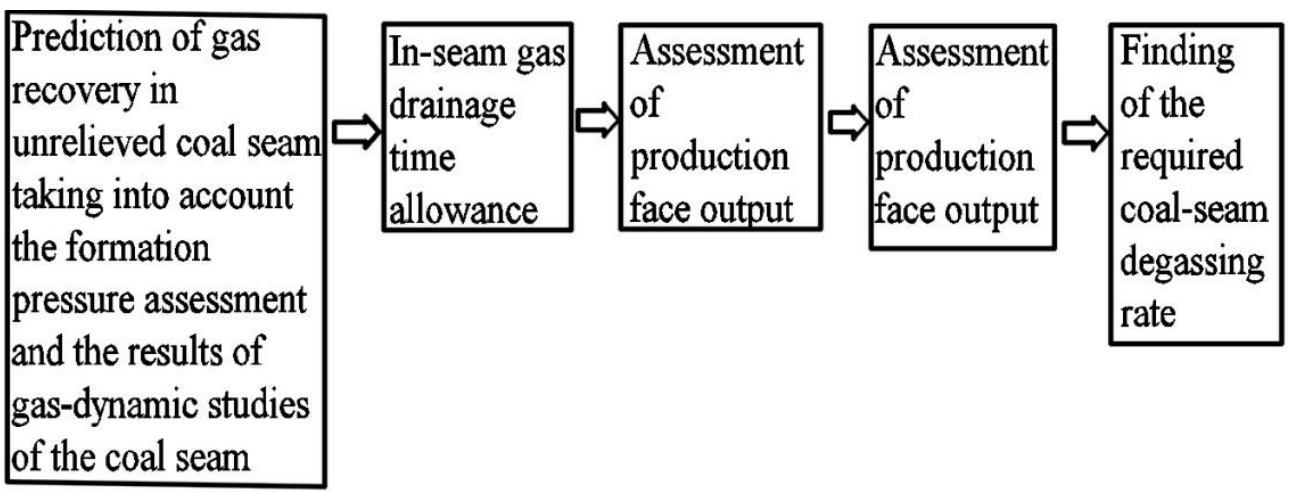

Figure 5. Methodological approach to defining the required effectiveness of in-seam gas drainage (Phase 1).

At the second stage (Table 2), the specific integrated in-seam gas drainage technology is selected (e.g., the conditions of Kirova mine with its extraction blocks 2458, 2459, 2460, 2462 and 2463, 2464, 2465, the extraction of which is coming).

As it can be seen from Table 2, the choice of the in-seam degassing technology depends on the geological conditions of the mining site and the planned production indicators. The baseline technology provided for the drilling of degassing wells from underground mine workings justifies itself only for simple geological conditions and traditional rates of coal production. In this case, when the degassing rate is only $15 \%$, all the unrecovered gas ultimately enters the environment. The increase in the rate of coal production, in which coal companies are interested, necessitates deeper gas extraction from the seams, which simultaneously increases the share of its use and reduces emissions to the environment. Thus, an increase in the intensity of coal mining at the mines of JSC SUEK Kuzbass, which has the necessary mining equipment, also leads to a decrease in methane emissions into the environment. 
Table 2. Recommended practice for selecting the most viable method of in-seam gas drainage for high-production mining panels (Phase 2).

\begin{tabular}{|c|c|c|}
\hline $\begin{array}{l}\text { The Required } \\
\text { Coal-Seam } \\
\text { Degassing Rate }\end{array}$ & $\begin{array}{l}\text { Recommended Practice for } \\
\text { Selecting the Most Viable } \\
\text { Method of In-Seam Gas } \\
\text { Drainage }\end{array}$ & $\begin{array}{c}\text { Contents of the Recommended } \\
\text { Degassing Method, Application } \\
\text { Conditions }\end{array}$ \\
\hline 0.15 & Baseline scheme & $\begin{array}{c}\text { In-seam gas drainage from } \\
\text { underground workings }\end{array}$ \\
\hline 0.3 & $\begin{array}{c}\text { Baseline scheme }+ \text { Support } \\
\text { technology }\end{array}$ & $\begin{array}{c}\text { Support technology is UgHF } \\
\text { In-seam gas drainage from } \\
\text { underground workings is used in zones } \\
\text { of UgHF }\end{array}$ \\
\hline 0.3 & $\begin{array}{l}\text { Baseline scheme }+ \text { Support } \\
\text { technology }+ \text { enhancement } \\
\text { technique }\end{array}$ & $\begin{array}{l}\text { The enhancement technique is used in } \\
\text { cases where the use of the baseline and } \\
\text { support technology did not go well and } \\
\text { does not guarantee the achievement of } \\
\text { the required coal-seam degassing rate, } \\
\text { but there is some margin of time for the } \\
\text { implementation of an additional } \\
\text { method of intensification, for example, } \\
\text { auto-pneumatic impact (API) }\end{array}$ \\
\hline $0.3-0.5$ & $\begin{array}{l}\text { Hydraulic loosening of a coal } \\
\text { seam carried out through } \\
\text { wells drilled from the surface } \\
\text { (SSHL) as a basic degassing } \\
\text { scheme + support technology } \\
\text { (in-seam gas drainage from } \\
\text { underground workings is } \\
\text { used in zones of UgHF) + } \\
\text { enhancement technique (API) }\end{array}$ & $\begin{array}{c}\text { Difficult mining and geological } \\
\text { conditions, such as, at extraction } \\
\text { sections } 2463,2464 \text { and } 2465 \text {. } \\
\text { Time reserve for seam degassing of at } \\
\text { least two years }\end{array}$ \\
\hline
\end{tabular}

\subsection{Prospects for the Use of Integrated Degassing Technology at the Kirov Mine}

The Kirov mine has modern high-performance degassing equipment, which opens up opportunities for widespread use of the proposed integrated degassing technology. The coal seam gas drainage work procedure, whereby $\mathrm{HL}$ is performed using surface boreholes, most commonly includes three main phases: (1) hydrodynamic impact; (2) well completion (removal of working fluid from the seam using pumps or in-seam wells, gas extraction); and (3) gas extraction from the worked out space after wells have been negotiated by the longwall operations.

Early gas drainage through the surface wells is normally effective when the methane extraction period is more than 3 years [39,51]. However, it is possible to reduce this time to less than 3 years, draining the HL zone by discharging water into the mine workings.

Surface wells are located at a distance of at least $300 \mathrm{~m}$ from the existing workings, in the direction of the main system of natural fissures in coal seams. If there is a fault with an amplitude greater than the thickness of the seam, wells are located also at a distance not less than its zone of influence.

Currently, the main factor complicating the running of mining operations is rock pressure, which increases with the development of mining (extraction sections 2463, 2464, and 2465). Under these conditions, the proposed combined degassing technologies, first used in Russia, have great prospects for ensuring intensive safe coal mining and reducing emissions of the greenhouse gas methane into the environment. Some additional material can be found at Supplementary Section.

The parameters of in-seam gas drainage should also take into account the availability and location of tectonically stressed and tectonically relieved zones that could be identified by geodynamic zoning $[50,52]$. The latter aspect is the subject of additional research. 


\section{Conclusions}

The increase in the rate of coal production, in which coal companies are interested, necessitates deeper gas extraction from seams, which simultaneously increases the share of its use and reduces emissions to the environment. Thus, an increase in the intensity of coal mining at the mines of JSC SUEK Kuzbass, which has the necessary mining equipment, helps to reduce methane emissions into the environment.

Analysis performed for a number of production blocks of the Kirova mine on restrictions imposed on the face output by the gas factor shows that the required coal-seam degassing rate should be up to $0.3(30 \%)$ for the majority of production faces. Under favorable conditions, this can be achieved by means of advanced gas drainage operations carried out from development headings (in particular, the technological version of integrated degassing using underground hydraulic fracturing, as shown in Table 2). This was confirmed by successful practices in the extraction blocks 2458, 2459, and 2460 at Kirova mine.

Mining is currently carried out at extraction block 2463, where in-seam gas drainage facilities include UgHF and advance in-seam gas drainage wells. Gas is drained from extraction block 2463, where the in-seam gas drainage complex also includes HL through surface wells. Studies on the relative and absolute gas content in production faces and downtime of mining equipment due to gas factor and mining intensity will make it possible to provide adequate assessment of how viable the tested in-seam gas drainage technologies are and estimate their feasibility and scope of their application.

It should be noted that Kirova mine, with its large-scale gas drainage project, is the first ever mining company to pioneer such practice in Russia. This initiative is not only undoubtedly of great interest to specialists in the field of ensuring the methane safety of underground coal mines, but also contributes to the above-mentioned discussion about the environmental impact of the mining industry, showing that an increase in mining intensity leads to a decrease in methane emissions in the environment. Additionally, this research could be useful for mono-industrial mining areas around the world $[53,54]$.

\section{Patents}

In this work, ideas from Russia Patent No. 2659 298, date 29 June 2018 (Slastunov S.V., Karkashadze G.G., Kolikov K.S., Yutyaev E.P., Mazanik E.V., Sadov A.P., Ponizov A.V., Nikitin S.G. "Method of preparing a gas-bearing coal seam for mining") about combined degassing technology were used.

Supplementary Materials: The following supporting information can be downloaded at: https: / / www.mdpi.com/article/10.3390/en15031047/s1, Figure S1: Photos of the equipment for hydraulic slotting of the target coal seam through wells drilled from the surface (SHS), field of Kirova mine. Figure S2: The graph of water download volume and download rate during hydraulic slotting process for the well No 1 at the experimental area. Figure S3: Graph of hydraulic slotting regime realization (the well No 1, experimental area). Figure S4: Graph of hydraulic slotting regime realization (the well No 3, experimental area). Figure S5: Connection equipment scheme for hydraulic slotting realization (Kirova mine). Figure S6: Photo of spontaneous water degassing (The well No 1, experimental area). Figure S7: Change in pressure in the hydraulic slotting borehole (No 2, experimental area ) when carrying out hydro fracturing in underground well No 63/5. Figure S8. Kirova mine. Block of the drainage station. Figure S9. Kirova mine. Methane power station. Figure S10. Kirova mine. Converted Coal Mine Methane Boiler.

Author Contributions: Conceptualization, S.S.; methodology, S.S. and K.K.; validation, S.S. and K.K.; formal analysis, S.S., K.K. and A.B.; investigation, S.S. and A.K.; resources, A.S.; data curation, S.S. and A.K.; writing — original draft preparation, S.S.; writing — review and editing, A.B.; visualization, A.K.; supervision, S.S. and A.S.; project administration, A.S.; funding acquisition, S.S. All authors have read and agreed to the published version of the manuscript.

Funding: The experimental works of this research have been done in accordance with contract No 5-45-K-M-2019 between JSC SUEK-Kuzbass (Leninsk-Kuznetsky 652507, Vasilyeva str. 1, Russia) 
and National University of Science and Technology «MISiS» (Moscow 119049, Leninsky Prospect, 4. Russia). Also the theoretical works of this research have been done in accordance with the Agreement on the provision of grants from the federal budget Russian Federation to the form of subsidies, No 075-15-2021-969 dated 23 September 2021.

Institutional Review Board Statement: Not applicable.

Informed Consent Statement: Not applicable.

Data Availability Statement: The data presented in this study are available on request from the corresponding author. The data are not publicly available due to the reports about results of the experimental works between the private company (JSC SUEK-Kuzbass) and the University "MISiS" is not obligatory for publication.

Acknowledgments: The authors acknowledge the invaluable contribution to the present work from JSC SUEK-Kuzbass Director General Yutyayev E.P., we also appreciate the help of Gas Drainage and Utilization Department team who collaborated in this work at Kirova mine, the Company headed by E. P. Yutyaev.

Conflicts of Interest: The authors declare no conflict of interest.

\section{References}

1. Coal Industry across Europe. The European Association for Coal and Lignite. 2020. Available online: https://euracoal.eu/info/ coal-industry-across-europe/ (accessed on 1 December 2021).

2. Reker, B.; Westermann, S.; Goerke-Mallet, P.; Melchers, C. Mine Water Rebound Processes in Europe. Paper Presented at the 2020 SME Annual Conference and Expo. 2020. Available online: https://www.researchgate.net/publication/31890773 6_Evaluation_of_mine_water_rebound_processes_in_European_Coal_Mine_Districts_to_enhance_the_understanding_of_ hydraulic_hydrochemical_and_geomechanical_processes/citations (accessed on 1 December 2021).

3. Velicu, I. De-growing environmental justice: Reflections from anti-mining movements in Eastern Europe. Ecol. Econ. 2019, 159, 271-278. [CrossRef]

4. Dey, S.D.; Singh, R. Mapping precarious energy geographies: Exploring the lived experience of coal mining in Jharia, India. Energy Res. Soc. Sci. 2021, 82, 102298. [CrossRef]

5. Rîșteiu, N.T.; Crețan, R.; O’Brien, T. Contesting post-communist economic development: Gold extraction, local community, and rural decline in Romania. Eurasian Geogr. Econ. 2021, 1-23. [CrossRef]

6. Hirschi, J.C. The role of research in the coal-mining industry: Moving forward using lessons from the past. In Advances in Productive, Safe, and Responsible Coal Mining; Elsevier: Amsterdam, The Netherlands, 2018; pp. 303-312.

7. Qiao, J.; Wang, Z.; Zhao, J. The evolution of thick coal seams mining methods in China. Min. Inf. Anal. Bull. 2020, 2020, 105-117. [CrossRef]

8. Ghosh, D. “We don't want to eat coal”: Development and its Discontents in a Chhattisgarh district in India. Energy Policy 2016, 99, 252-260. [CrossRef]

9. Connor, L.H. Energy futures, state planning policies and coal mine contests in rural New South Wales. Energy Policy 2016, 99, 233-241. [CrossRef]

10. Myaskov, A.V.; Popov, E.M.; Popov, S.M. Prospects for the use of mines in East Donbass as underground gas storage facilities in the integral gas-supply system of Southern Russia. Gornyi Zhurnal 2018, 33-36. [CrossRef]

11. Nguyen, B.N.; Boruff, B.; Tonts, M. Looking through a crystal ball: Understanding the future of Vietnam's minerals and mining industry. Extr. Ind. Soc. 2021, 8, 100907. [CrossRef]

12. Ordonez, J.A.; Jakob, M.; Steckel, J.C.; Fünfgeld, A. Coal, power and coal-powered politics in Indonesia. Environ. Sci. Policy 2021, 123, 44-57. [CrossRef]

13. Wang, W.; Fan, L.; Zhou, P. Evolution of global fossil fuel trade dependencies. Energy 2022, 238, 121924. [CrossRef]

14. Vesalon, L.; Creţan, R. 'Cyanide kills!' Environmental movements and the construction of environmental risk at Roşia Montană, Romania. Area 2013, 45, 443-451. [CrossRef]

15. Guo, K.; Chen, Y.; Chen, M.; Wang, C.; Chen, Z.; Cai, W.; Li, R.; Feng, W.; Jiang, M. Causal Analysis of Ecological Impairment in Land Ecosystem on a Regional Scale: Applied to a Mining City Daye, China. Land 2021, 10, 530. [CrossRef]

16. Altowilib, A.; AlSaihati, A.; Alhamood, H.; Alafnan, S.; Alarifi, S. Reserves Estimation for Coalbed Methane Reservoirs: A Review. Sustainability 2020, 12, 10621. [CrossRef]

17. Borowski, M.; Życzkowski, P.; Zwolińska, K.; Łuczak, R.; Kuczera, Z. The Security of Energy Supply from Internal Combustion Engines Using Coal Mine Methane-Forecasting of the Electrical Energy Generation. Energies 2021, 14, 3049. [CrossRef]

18. Sanmiquel-Pera, L.; Bascompta, M.; Anticoi, H.F. Analysis of a Historical Accident in a Spanish Coal Mine. Int. J. Environ. Res. Public Health 2019, 16, 3615. [CrossRef]

19. Zheng, C.; Jiang, B.; Xue, S.; Chen, Z.; Li, H. Coalbed methane emissions and drainage methods in underground mining for mining safety and environmental benefits: A review. Process. Saf. Environ. Prot. 2019, 127, 103-124. [CrossRef] 
20. Wu, C.; Yuan, C.; Wen, G.; Han, L.; Liu, H. A dynamic evaluation technique for assessing gas output from coal seams during commingling production within a coalbed methane well: A case study from the Qinshui Basin. Int. J. Coal Sci. Technol. 2020, 7, 122-132. [CrossRef]

21. Zhao, Z.M.; Wang, G. The Research of Gas Drainage Technology in Daning Coal Mine. Appl. Mech. Mater. 2014, 580-583, 2558-2563. [CrossRef]

22. Karacan, C.Ö.; Ruiz, F.A.; Cotè, M.; Phipps, S. Coal mine methane: A review of capture and utilization practices with benefits to mining safety and to greenhouse gas reduction. Int. J. Coal Geol. 2011, 86, 121-156. [CrossRef]

23. Hu, C.; Wu, D. A novel gas drainage technology for lower protected coal seams: Application and verification in xin-zhuangzi coal mine, huainan coalfield. IPPTA Q. J. Indian Pulp Pap. Tech. Assoc. 2018, 30, 801-808.

24. Hu, G.; Xu, J.; Zhang, F.; Zhao, C.; Qin, W.; Zhu, Y. Coal and Coalbed Methane Co-Extraction Technology Based on the Ground Movement in the Yangquan Coalfield, China. Energies 2015, 8, 6881-6897. [CrossRef]

25. Gas Drainage Instructions. Moscow. 2012. Available online: https://meganorm.ru/Data2/1/4293797/4293797769.pdf (accessed on 1 December 2021).

26. Lu, Y.Y.; Zhang, H.D.; Zhou, Z.; Ge, Z.L.; Chen, C.J.; Hou, Y.D.; Ye, M.L. Current Status and Effective Suggestions for Efficient Exploitation of Coalbed Methane in China: A Review. Energy Fuels 2021, 35, 9102-9123. [CrossRef]

27. Petukhov, I.M. Forecasting and combating rockbursts: Recent developments. In Proceedings of the 6th Congress International Society for Rock Mechanics, Montreal, QC, Canada, 30 August-3 September 1987; Volume 2, pp. 1207-1210.

28. Zhu, Z.; Zhang, H.; Nemcik, J.; Lan, T.; Han, J.; Chen, Y. Overburden movement characteristics of top-coal caving mining in multi-seam areas. Q. J. Eng. Geol. Hydrogeol. 2018, 51, 276-286. [CrossRef]

29. Zhang, L.; Zhang, H.; Guo, H. A case study of gas drainage to low permeability coal seam. Int. J. Min. Sci. Technol. 2017, 27, 687-692. [CrossRef]

30. Li, Q.; Lu, Y.; Ge, Z.; Zhou, Z.; Zheng, J.; Xiao, S. A New Tree-Type Fracturing Method for Stimulating Coal Seam Gas Reservoirs. Energies 2017, 10, 1388. [CrossRef]

31. Álvarez-Fernández, M.-I.; Prendes-Gero, M.-B.; Peñas-Espinosa, J.-C.; González-Nicieza, C. Innovative Techniques in Underground Mining for the Prevention of Gas Dynamic Phenomena. Energies 2021, 14, 5205. [CrossRef]

32. Vishal, V.; Mahanta, B.; Pradhan, S.; Singh, T.; Ranjith, P. Simulation of CO2 enhanced coalbed methane recovery in Jharia coalfields, India. Energy 2018, 159, 1185-1194. [CrossRef]

33. Huang, B.; Lu, W.; Chen, S.; Zhao, X. Experimental investigation of the functional mechanism of methane displacement by water in the coal. Adsorpt. Sci. Technol. 2020, 38, 357-376. [CrossRef]

34. Xu, G.; Huang, J.; Hu, G.; Yang, N.; Zhu, J.; Chang, P. Experimental study on effective microwave heating/fracturing of coal with various dielectric property and water saturation. Fuel Process. Technol. 2020, 202, 106378. [CrossRef]

35. Wang, H.; Merry, H.; Amorer, G.; Kong, B. Enhance hydraulic fractured coalbed methane recovery by thermal stimulation. In Proceedings of the Society of Petroleum Engineers-SPE/CSUR Unconventional Resources Conference, Society of Petroleum Engineers, Calgary, AB, Canada, 20-22 October 2015. [CrossRef]

36. Slastunov, S.V.; Yutyaev, E.P. Justified selection of a seam degassing technology to ensure safety of intensive coal mining. J. Min. Inst. 2017, 223, 125-130. [CrossRef]

37. Gao, Y.; Lin, B.; Yang, W.; Li, Z.; Pang, Y.; Li, H. Drilling large diameter cross-measure boreholes to improve gas drainage in highly gassy soft coal seams. J. Nat. Gas Sci. Eng. 2015, 26, 193-204. [CrossRef]

38. Hao, C.; Cheng, Y.; Liu, H.; Wang, L.; Liu, Q. A novel technology for high-efficiency borehole-enlarging to enhance gas drainage in coal seam by mechanical cutting assisted by waterjet. Energy Sources Part A Recover. Util. Environ. Eff. 2019, 1-18. [CrossRef]

39. Nozhkin, N.V. Advance Degassing of Coal Deposits; Nedra: Moscow, Russia, 1979; 271p.

40. Kurlenya, M.V.; Serdyukov, S.V.; Shilova, T.V.; Patutin, A.V. Procedure and equipment for sealing coal bed methane drain-age holes by barrier shielding. J. Min. Sci. 2015, 50, 994-1000. [CrossRef]

41. Wang, K.; Lou, Z.; Wei, G.; Lu, W.; Du, F.; Qin, B. Reasonable minimum sealing length of in-seam boreholes for coal mine methane drainage: A case study. Energy Sources Part A Recover. Util. Environ. Eff. 2020, 42, 2199-2213. [CrossRef]

42. Guo, X.; Xue, S.; Li, Y.; Zheng, C.; Xie, L. Research on Optimization of Key Areas of Drainage Borehole Sealing in Ultrathick Coal Seam. Shock. Vib. 2021, 2021, 5536196. [CrossRef]

43. Szott, W.; Słota-Valim, M.; Gołąbek, A.; Sowiżdżał, K. Numerical studies of improved methane drainage technologies by stimulating coal seams in multi-seam mining layouts. Int. J. Rock Mech. Min. Sci. 2018, 108, 157-168. [CrossRef]

44. Wang, Q.; Zhao, Y.; Li, C.; Xie, B.; Xue, H. Experimental and numerical simulation study on the dynamic fracture of coal by gas expansion. Energy Sci. Eng. 2020, 8, 3047-3059. [CrossRef]

45. Zhu, C.; Liu, S.; Chen, X.; Wu, H.; Lin, B.; Liu, T.; Li, L. High-pressure water and gas alternating sequestration technology for low permeability coal seams with high adsorption capacity. J. Nat. Gas Sci. Eng. 2021, 96, 104262. [CrossRef]

46. Yan, F.; Lin, B.; Zhu, C.; Shen, C.; Zou, Q.; Guo, C.; Liu, T. A novel ECBM extraction technology based on the integration of hydraulic slotting and hydraulic fracturing. J. Nat. Gas Sci. Eng. 2015, 22, 571-579. [CrossRef]

47. Slastunov, S.V.; Yutyaev, E.P.; Mazanik, E.V.; Sadov, A.P.; Ponizov, A.V. Mine testing improved technology underground res-ervoir degassing with the use of hydraulic fracturing. Ugol 2016, 11, 32-37. [CrossRef]

48. Kulikova, A.; Ovchinnikova, T. On the issue of reducing geoecological risks at mining enterprises. Min. Inf. Anal. Bull. 2021, 86, 251-262. [CrossRef] 
49. Novoselov, S.V.; Melnik, V.V.; Agofonov, V.V. Year of ecology in russia and approaches to resolving geoecologi-cal problems in kuzbass. Ugol 2017, 3, 78-79. [CrossRef]

50. Yutyaev, E.P. Substantiation of Underground Geotechnology for Intensive Development of Flat Gas-Bearing Seams in Coal Mines. Ph.D. Thesis, Kuzbass State Technical University, Kemerovo, Russia, 2009.

51. Interim Guidance for Pre-Preparation of the Mining Fields to the Effective Development of Wells with the Surface Pneumo-Hydrodrives the Retinue of Coal Seams; Mining Institute: Moscow, Russia, 1991; 92p.

52. Batugina, I.M.; Petukhov, I.M. Geodynamic Zoning of Mineral Deposits for Planning and Exploitation of Mines; Oxford and IBH Publishing Co. Pvt. Ltd.: New Delhi, India, 1990.

53. Vesalon, L.; Creţan, R. Mono-industrialism and the Struggle for Alternative Development: The Case of the Roşia Montană Gold-mining Project. Tijdschr. Econ. Soc. Geogr. 2013, 104, 539-555. [CrossRef]

54. Batugina, N.S.; Gavrilov, V.L.; Tkach, S.M. Validation of local coal supply effectiveness in the hard-to-reach Arctic zones in Yakutia. In Proceedings of the IOP Conference Series: Earth and Environmental Science; IOP Publishing: Bristol, UK, 2021 ; Volume 773. 